\title{
Gonadal investment of young males in two blenniid fishes with alternative mating tactics
}

\author{
R. F. Oliveira* + , E. J. Gonçalves* and R. S. Santos $\dagger$ \\ *Unidade de Investigação em Eco-Etologia, Instituto Superior de Psicologia Aplicada, \\ Rua Jardim do Tabaco 34, 1149-041 Lisboa, Portugal and †Departamento de \\ Oceanografia e Pescas, Universidade dos Açores, 9901-862 Horta, Faial, Açores, \\ Portugal
}

(Received 30 October 2000, Accepted 25 April 2001)

\begin{abstract}
The males of two blenniid species which exhibited alternative life history tactics and matured in their first year of life varied in size distribution within the age class and in behaviour. Salaria pavo were the smaller fish of the age class and behaved as sneaker males whereas Parablennius sanguinolentus parvicornis were the larger fish and behaved as satellites.
\end{abstract}

(C) 2001 The Fisheries Society of the British Isles

Key words: alternative reproductive tactics; life-history; satellite behaviour; sneaker behaviour; Blenniidae.

In several species with size dependent male mating success less competitive males may adopt alternative mating tactics to reproduce (Gross, 1996). Thus, two mating tactics can be adopted by males, a bourgeois tactic, used by males that actively compete and invest in the acquisition of mates, and a parasitic tactic, adopted by males that exploit the investment of bourgeois males to get access to females and fertilize eggs (Taborsky, 1997). These alternative reproductive tactics are widespread in teleost fishes, i.e. 140 species of 28 families (Taborsky, 1998). In blenniid fishes two species in which alternative reproductive tactics occur are the peacock blenny Salaria pavo (Risso, 1810) and the Azorean rock-pool blenny Parablennius sanguinolentus parvicornis (Valenciennes in Cuvier \& Valenciennes, 1836) (Santos, 1985; Ruchon et al., 1995; Gonçalves et al., 1996). Interestingly, the tactic used by the kleptogamic males is different between these two species, which offers a unique opportunity for a comparative study of alternative reproductive tactics in closely related species.

In two populations of $S$. pavo living in coastal lagoons, Ria Formosa, Algarve, Portugal and Mauguio Lagoon, Gulf of Lion, France, where nest space is very scarce, male sexual polymorphism has been described (Ruchon et al., 1995; Gonçalves et al., 1996). In these two populations smaller and younger males adopt female nuptial colouration and female courtship behaviour towards nest-holder males (Gonçalves et al., 1996), as a means to try to enter the nest during or shortly after a female has spawned. The gonado-somatic index $\left(I_{\mathrm{G}}\right)$ of sneaker males in this species is approximately three and a half times higher than that of nest-holder males (Ruchon et al., 1995; Gonçalves et al., 1996).

In P. s. parvicornis some of the smaller and younger males become attached to parental territories, that are established by larger and older males, acting as satellites (Santos, 1985; Santos et al., 1995). Satellite males participate in the active defence of the parental territory and try to achieve sneak fertilization when females enter the nests to spawn

\$Author to whom correspondence should be addressed. Tel.: +351 21 8811700; fax: +351 218860954 ; email: ruiol@ispa.pt 
(Santos, 1985). The $I_{\mathrm{G}}$ of satellite males is approximately two times that of nest-holders (Santos et al., 1995).

Although in both species the kleptogamic males are $0+$ to 1 year of age $I_{\mathrm{G}}$ values of different age classes suggest that not all $0+$ to 1-year-old males are mature (Santos et al., 1995; Gonçalves et al., 1996). This means that alternative ontogenetic routes exist and are determined either genetically or by condition, e.g. body size.

The effect of relative size of 1-year-old males on their decision to invest in reproduction, i.e. gonadal tissue, in their first breeding season in the blenniid species $S$. pavo and $P$. s. parvicornis was investigated. It is predicted that gonadal investment should differ in young males of the two species according to their behaviour to achieve parasitic fertilization. Thus, it is expected that the smaller of the young $S$. pavo males are most likely to act as sneakers, because this tactic involves deception of the nest-holders, and thus size would be a potential handicap for female mimicry. In P. s. parvicornis the largest males are thought most likely to reproduce as satellites, since this tactic involves helping in defence and thus large body size should be an advantage.

All the data used in the present study were obtained from individuals collected for other research projects (Santos et al., 1995, 1996; Gonçalves et al., 1996). A total of 48 S. pavo males were collected during the breeding season (May to August) of 1990, 1991 and 1993 with a hand net at Ria Formosa, south Portugal. Samples were kept to a minimum and were collected over several years since this species is classified as vulnerable in Portugal (ICN, 1993). A total of 612 P. s. parvicornis males were collected during the breeding season (May to August) of 1987 and 1988, with and without the anaesthetic quinaldine in rock-pools at Feteira, Faial island, Azores. Males were sacrificed with an overdose of quinaldine, the total length $\left(L_{\mathrm{T}}\right)$ of each individual was measured to the nearest $\mathrm{mm}$ using dial callipers and the body mass $(W)$ was determined to the nearest $0 \cdot 01 \mathrm{~g}$. Gonad mass $\left(W_{\mathrm{G}}\right)$ was weighed to the nearest $0.01 \mathrm{mg}$. The gonado-somatic index $\left(I_{\mathrm{G}}\right)$ was estimated from $I_{\mathrm{G}}=100 W_{\mathrm{G}} W^{-1}$.

Age was determined from growth rings in sagittally sectioned otoliths, which were cleaned, cleared and then mounted in resin before reading under reflected light using a dark-field stereo microscope. Twenty-four S. pavo and 182 P. s. parvicornis were aged as $0+$ to 1 year after otolith examination and were used in the present analysis. There were no significant differences in young male $I_{\mathrm{G}}$ between years of collection $(1990 v .1991 v$. 1993 for $S$. pano, one-way ANOVA: $F_{2,21}=0 \cdot 33, P=0 \cdot 72 ; 1987 v$. 1988 for $P$. $s$. parvicornis, $t=1 \cdot 63, P=0 \cdot 11)$. Thus, data from different years were combined.

In $S$. pavo $I_{\mathrm{G}}$ decreased with body size $\left(L_{\mathrm{T}}\right)\left[I_{\mathrm{G}}=8 \cdot 03-0 \cdot 82 L_{\mathrm{T}}, r^{2}=0 \cdot 42, F_{1,22}=15.98\right.$, $P<0.001$, Fig. 1(a)], while in P. s. parvicornis it increased $\left[I_{\mathrm{G}}=-4 \cdot 05+0.69 L_{\mathrm{T}}, r^{2}=0 \cdot 13\right.$, $F_{1,180}=26.35, P<0.0001$, Fig. 1(b)]. The regression slopes were significantly different (ANCOVA: $F_{1,202}=15 \cdot 92, P<0 \cdot 001$ ).

Males that invest in gonadal tissue in their first year of life, and that are sexually active, are the smaller individuals in $S$. pavo and the larger in $P$. s. parvicornis. Thus, male size in their first breeding season is correlated with the 'decision' to invest precociously in reproduction. This does not mean that males breeding during their first year of life, as sneakers or satellites, cannot become nest-holders in subsequent breeding seasons. A preliminary mark-recapture field experiment has shown that $S$. pavo sneaker males can, in one breeding season, become nest-holders in subsequent breeding seasons (D. M. Gonçalves \& R. F. Oliveira, unpubl. data). Moreover, the administration of gonadal steroids to $S$. pavo sneakers and to $P$. $s$. parvicornis satellites can induce the development of male secondary sex characters within 1 week (Oliveira et al., 2001).

In $S$. pavo it could be argued that males with higher $I_{\mathrm{G}}$ were smaller because they tended to be collected earlier in the breeding season than males with a low $I_{\mathrm{G}}$. This was not the case because no differences in $I_{\mathrm{G}}$ between different years of collection were found and in each year individuals were sampled in different months of the breeding season.

If these alternative ontogenetic routes are not genetically determined, possible explanations could be that males have different growth rates or there is a birthdate effect. The first hypothesis has already been established for salmonid species in which alternative male mating tactics also occur (Myers et al., 1986). If the second hypothesis applies, males born at different times in the breeding season will reach the next breeding season 

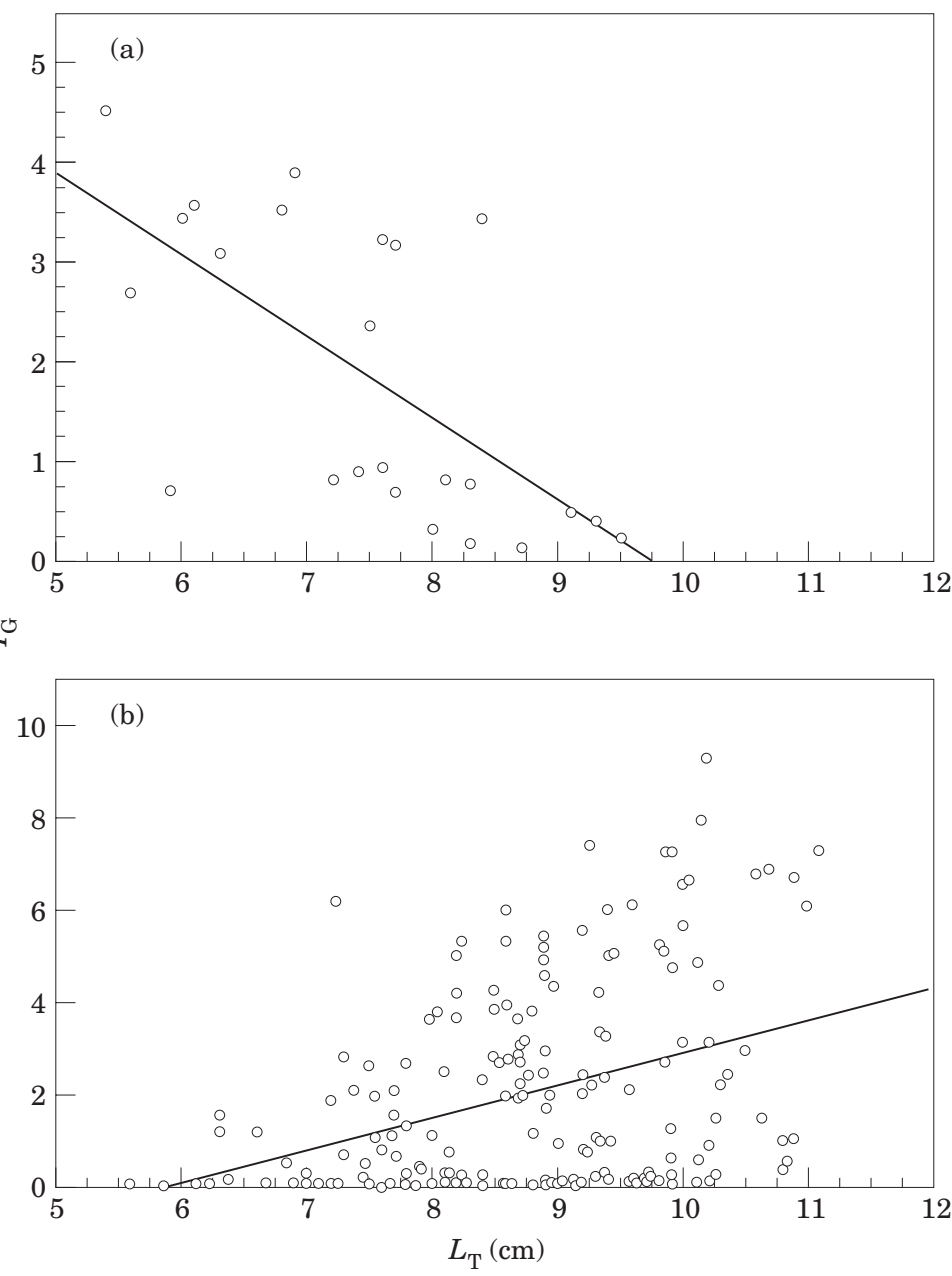

FIG. 1. Relationship between gonado-somatic index $\left(I_{\mathrm{G}}\right)$ and body size $\left(L_{\mathrm{T}}\right)$ among young males of two blenniid species with alternative reproductive tactics. (a) S. pavo; (b) P. s. parvicornis.

at different sizes. This would explain why there is an advantage for some individuals to invest in reproduction in their first breeding season while others continue to grow and become sexually mature only in subsequent breeding seasons. This hypothesis has been designated the birthdate effect and has the assumption that early and late born individuals in a given breeding season have equal growth rates (Taborsky, 1998). From the birthdate hypothesis it can be predicted that in the peacock blenny those males born late in the season are the ones that would invest in reproduction in the next breeding season while in the rock-pool blenny early born individuals would act as satellites in their first breeding season.

The data reported here strongly suggest that to be a sneaker or a satellite depends on different conditional fitness relationships with body size. In the sneaker male, fitness should decrease with body size while in the satellite male fitness should increase with body size. However, both may have a common tactic switching point, when the fitness curve for sneaker and satellite behaviour intersects the bourgeois behaviour fitness curve. The differences between sneaker and satellite development would thus impose a sizedependent behavioural constraint on which individuals may follow each ontogenetic alternative pathway, that is to breed or not in their first year. 
The preparation of this paper was supported by PRAXIS XXI and FEDER (Praxis/PCNA/C/BIA/94/ 96). The authors would like to thank V. Almada, A. J. dos Santos, R. Nash and S. Hawkins who collaborated in the original studies reported in this paper and M. Taborsky for helpful comments on an earlier version of the manuscript. We also thank N. Serpa, O. Amaral and C. Leal for help in the laboratory and field.

\section{References}

Gonçalves, E. J., Almada, V. C., Oliveira, R. F. \& Santos, A. J. (1996). Female mimicry as a mating tactic in males of the blenniid fish Salaria pavo. Journal of the Marine Biological Association of the United Kingdom 76, 529-538.

Gross, M. R. (1996). Alternative reproductive strategies and tactics: diversity within sexes. Trends in Ecology and Evolution 11, 92-98.

ICN, Instituto da Conservacõ da Natureza (1993). Livro Vermelho dos Vertebrados de Portugal, Vol. 3. Peixes Marinhos e Estuarinos. Lisboa: ICN.

Myers, R. A., Hutchings, J. A. \& Gibson, R. J. (1986). Variation in male parr maturation within and among populations of Atlantic salmon, Salmo salar. Canadian Journal of Fisheries and Aquatic Sciences 43, 1242-1248.

Oliveira, R. F., Canario, A. V. M. \& Grober, M. S. (2001). Male sexual polymorphism, alternative reproductive tactics and androgens in Combtooth Blennies (Pisces: Blenniidae). Hormones and Behavior, in press.

Ruchon, F., Laugier, T. \& Quignard, J. P. (1995). Alternative male reproductive strategies in the peacock blenny. Journal of Fish Biology 47, 826-840.

Santos, R. S. (1985). Parentais e satélites: tácticas alternativas de acasalamento nos machos de Blennius sanguinolentus Pallas (Pisces: Blenniidae). Arquipélago, Life \& Earth Sciences 6, 119-146.

Santos, R. S., Nash, R. D. M. \& Hawkins, S. J. (1995). Age, growth and sex ratio of the Azorean rock-pool blenny, Parablennius sanguinolentus parvicornis. Journal of the Marine Biological Association of the United Kingdom 75, 751-754.

Santos, R. S., Hawkins, S. J. \& Nash, R. D. M. (1996). Reproductive phenology of the Azorean rock pool blenny a fish with alternative mating tactics. Journal of Fish Biology 48, 842-858.

Taborsky, M. (1997). Bourgeois and parasitic tactics: do we need collective, functional terms for alternative reproductive behaviours? Behavioral Ecology and Sociobiology 41, 361-362.

Taborsky, M. (1998). Sperm competition in fish: 'bourgeois' males and parasitic spawning. Trends in Ecology and Evolution 13, 222-227. 